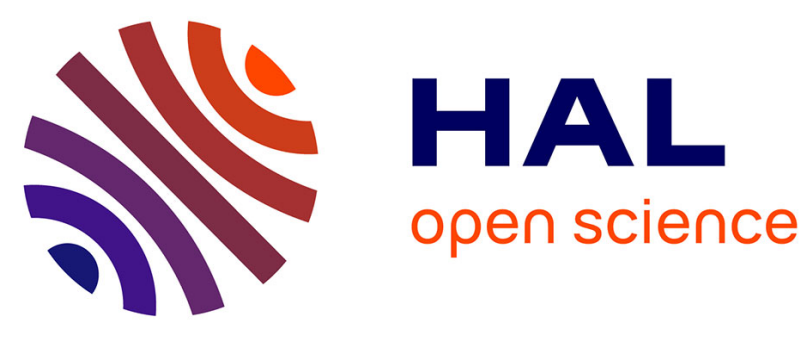

\title{
Small-scale food process engineering - Challenges and perspectives
}

Hugo de Vries, Michel Mikolajczak, Jean-Michel Salmon, Joel Abecassis, Laurent Chaunier, Sofiane Guessasma, Denis Lourdin, Sofiane Belhabib, Eric Leroy, Gilles Trystram

\section{To cite this version:}

Hugo de Vries, Michel Mikolajczak, Jean-Michel Salmon, Joel Abecassis, Laurent Chaunier, et al.. Small-scale food process engineering - Challenges and perspectives. Innovative Food Science \& Emerging Technologies / Innovative Food Science and Emerging Technologies , 2017, 46, pp.122-130. 10.1016/j.ifset.2017.09.009 . hal-01608579

\section{HAL Id: hal-01608579 \\ https://hal.science/hal-01608579}

Submitted on 27 May 2020

HAL is a multi-disciplinary open access archive for the deposit and dissemination of scientific research documents, whether they are published or not. The documents may come from teaching and research institutions in France or abroad, or from public or private research centers.
L'archive ouverte pluridisciplinaire HAL, est destinée au dépôt et à la diffusion de documents scientifiques de niveau recherche, publiés ou non, émanant des établissements d'enseignement et de recherche français ou étrangers, des laboratoires publics ou privés.

\section{다(1)(2)}

Distributed under a Creative Commons Attribution - ShareAlikel 4.0 International 


\section{Accepted Manuscript}

Small-scale food process engineering - Challenges and perspectives

De Vries Hugo, Michel Mikolajczak, Jean-Michel Salmon, Joël Abecassis, Laurent Chaunier, Sofiane Guessasma, Denis Lourdin, Sofiane Belhabib, Eric Leroy, Gilles Trystram

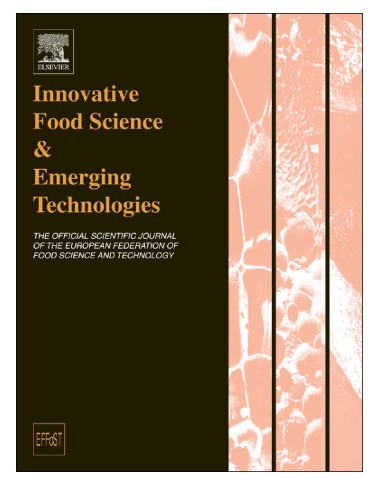

PII:

S1466-8564(17)30264-3

DOI: doi: 10.1016/j.ifset.2017.09.009

Reference: INNFOO 1847

To appear in: Innovative Food Science and Emerging Technologies

Received date: 1 March 2017

Revised date: 7 August 2017

Accepted date:

13 September 2017

Please cite this article as: De Vries Hugo, Michel Mikolajczak, Jean-Michel Salmon, Joël Abecassis, Laurent Chaunier, Sofiane Guessasma, Denis Lourdin, Sofiane Belhabib, Eric Leroy, Gilles Trystram, Small-scale food process engineering - Challenges and perspectives, Innovative Food Science and Emerging Technologies (2017), doi: 10.1016/ j.ifset.2017.09.009

This is a PDF file of an unedited manuscript that has been accepted for publication. As a service to our customers we are providing this early version of the manuscript. The manuscript will undergo copyediting, typesetting, and review of the resulting proof before it is published in its final form. Please note that during the production process errors may be discovered which could affect the content, and all legal disclaimers that apply to the journal pertain. 


\section{Small-scale food process engineering - challenges and perspectives}

De Vries Hugo*1 ${ }^{*}$ Michel Mikolajczak ${ }^{2}$, Jean-Michel Salmon ${ }^{2}$, Joël Abecassis ${ }^{1}$, Laurent Chaunier ${ }^{3}$, Sofiane Guessasma ${ }^{3}$, Denis Lourdin ${ }^{3}$, Sofiane Belhabib ${ }^{4}$, Eric Leroy ${ }^{5}$, Gilles Trystram*6

${ }^{1}$ IATE, CIRAD, INRA, Montpellier SupAgro, U. Montpellier, 2 Place Viala, 34060 Montpellier, France

${ }^{2}$ Unité Expérimentale de Pech-Rouge, INRA, 11430 Gruissan, France

${ }^{3}$ BIA, INRA, Rue de la géraudière, 44316 Nantes, France

${ }^{4}$ UBL, Université Bretagne Loire. CNRS, GEPEA UMR-CNRS-6144, IUT de Nantes, 2 avenue du Professeur Jean Rouxel, 44475 Carquefou Cedex, France

${ }^{5}$ UBL, Université Bretagne Loire. CNRS, GEPEA UMR-CNRS-6144, CRTT, 37 avenue de I'Université, 44606 St-

Nazaire Cedex, France

${ }^{6}$ AgroParisTech, INRA, UMR 1145, Avenue des Olympiades, 91300 Massy, France

*corresponding authors: hugo.de-vries@inra.fr_and gilles.trystram@agroparistech.fr

\section{Abstract}

Technological innovations in the food sector have been driven by high-volume production lines over the past decades. Cost-efficiency of processing and price competitiveness of final products have been major factors. The economics of up-scaling have led to new technologies that are more efficient in terms of throughput and utilization of (homogenous) resources. The question now is whether there is a future for competitive, sustainable processing at small scale. To answer that question, we address two major issues. The first deals with process efficiency and the reliability and resilience of technologies for small-scale processing to be competitive. The second deals with localization of processing and the advantages and disadvantages of technologies for small-scale processing. Novel technologies, especially those based on electro-thermo-dynamic principles, may emerge with characteristics that appear more beneficial for applications at small-scale, and so may well contribute to the competitiveness of local producers of food and biobased products valorizing renewable resources in an integrated manner for a variety of business sectors. However, these novel technologies should go hand in hand with end-to-end innovation of the local food and biobased product system in order to be competitive with international-scale enterprises.

Keywords: modeling; printability; food physics; food systems; complex biobased systems; food engineering; 


\section{Introduction}

The kind of food innovations emerging in recent years has changed to increasingly put consumer expectations at the starting point for innovation. Consideration of the Earth's potential, global changes (especially climate change) and the impact of human activities on the environment make it time to write a new chapter on the key issue of 'the development of sustainable food products'. A systemic vision on food systems is now emerging, driven by new applications and the connection between agriculture and food design. It sees the food system as the way in which people organize themselves in space and time to obtain and consume their food (Rastoin et al., 2010). The concept is extended to sustainable food systems (FAO, 2010 for example), whose objectives are to be protective and respectful of biodiversity and ecosystems, to be culturally acceptable and accessible, to be economically fair and affordable, to be nutritionally adequate, safe and healthy and to optimise natural and human resources. Sustainability is clearly a major objective, and of food production has a potentially huge contribution to make in reaching sustainable development goals (SDG) (UN, 2016) as it concerns at least 10 of the 17 SDGs. There is absolutely no doubt that the emerging food system will be key to maintaining a viable planet Earth, due to ist role in food security issues, nutrition efficiency needs and preventive health strategies, on to environmental protection, water and energy savings, and the ability of humans to live long and stay fit.

Historically, all food systems started out locally with a strong dose of 'eco-conception' needed to survive. Food engineering is mankind's oldest engineering activity, serving to transform renewable resources into eatable food parts. In recent history, the trend has been towards globalization, largevolume production, and from batch to continuous processing. The push came from production and technology: food security became an increasingly pressing issue with globalized food chains and the need to transform diverse mainstream-often homogenous-raw material into a variety of products. This approach has led to the situation today, where we can sufficiently produce and process in a continuous manner. However, the distribution of and access to food remains unfair for a substantial part of the world's population, and its environmental impact is still often huge. The of peopleplanet-profit triple bottom line is only thus part fulfilled, as we lack prosperity and diversity for all.

The past 20 years saw a chain reversal, resulting in reviewing and better understanding consumer demands, needs, preferences and perceptions (organic, dashboard dining, convenience, culturally trendy, and so on). The social aspect of sustainability and the 'economic added value concepts' then followed as drivers for processing, although pushed by multinationals often based in developed countries. This surfaced the concept of reverse chain/engineering thinking (fork back to farm) for the globalized mass production system with a diverse but limited number of functional products (Meynard et al., 2016, Perrot et al., 2015). This has upped the role of ingredients to increase the variety of end-products, leading to a long list of innovations in the ingredient area this decade.

The appreciation of diversity of end-products was followed by a re-introduction of batch processing, especially in the kitchen. A limited number of companies conquered the market with a series of safe and standardized kitchen appliances. The 'we are all chefs' slogan has been strongly promoted and broadcasted; in fact, we are all food engineers returning to our historical roots and preparing our own eatable products, even if this activity takes up only a minor share of our daily life.

The millennium development goal debates refocalized, concerns over sufficient resources for a growing and more urbanized world population to share a viable planet and the need to preserve the 
local heritage of the food system (Rastoin et al., 2010). The socioeconomic and environmental dimensions of sustainability were re-introduced in large mega-programs with a specific emphasis on how to reduce the loss of resources and to redistribute more fairly today. Here, then, the ethical and social concerns are thus a priori related to the local-global dilemma.

The net result is that foods and food systems have to evolve. The number of innovations is huge, and the dynamic is impressive. We have arrived at a crossroads, with at least 3 directions to take.

The first direction concerns a better efficiency of the existing agrifood industry. One of the benefits of this major food system is that it enables mass production, the search for the lowest possible price, and immediate large-scale impact of a single innovation. Reducing energy and water consumption, losses and wastes remains an essential task, both at industrial and artisanal levels. Novel agrifood logistics concepts with strong ties to consumer behavior and new technologies (mainly digital-based) are fueling recent and forthcoming innovations, many of which are not directly visible to consumers. The new paradigm for food processing is the surge in diversity of agricultural resources that need to be transformed, which directly challenges the scale and size of food technologies.

The second direction is the search for innovative food products, mainly based on product design, services and consumer-driven innovations (including digital disruption). It has spurred an amazing set of innovative products, and offers three main axes for existing and future product design pathways:

- The notion of perception-developing new perceptions or maintaining existing ones-for newly-designed food. Old perceptions are driven by nutritional considerations such as reducing key nutrients like salt, fat and sugar. New perceptions are often related to composite foods, products that are engineered by combining different structures in order to produce original sensations (in exactly the same way as a chef does). This is probably one of the most important directions for innovative food products such as innovative foams, emulsions or gels as combined structures, which makes deep knowledge of micro-structuring and distribution of components imperative.

- Tailor-made food and the search for niche products with a high added value, hence produced at relatively small scales. The substitution of animal-origin proteins by plant proteinswhether from field crops like major cereals or small local productions such as specific legumes-is also one of the important avenues for innovation.

- Health considerations leading to the search for encapsulated-either at nano- or microscale-active biomolecules while optimizing bioavailability and transfer mechanisms for (fragments of those) biomolecules.

The third direction of the food systems would be to re-think the localization of production, transformation and consumption of resources, in order to save energy and water as the principal environmental aim as well as local employment and cultural heritage as further socioeconomic aims. Big factories generally concentrate the key steps of food transformation in an effort to stay efficient and makeeconomies of scale. Nevertheless, this system is running into emergent issues like ecological concerns and the impacts of such concentrations on social cohesion or employment, to name but a few. The most interesting localization would be a place as close as possible to the agricultural resources and transformation opportunities. Extraction, purification, preservation and heat processing are key operations that are then reorganized closer to the production of resources. 
The consequence is not necessarily visible on the perceived food itself, but the impact on the environment and the water footprint, for example, is much lower.

On the other side of the equation, there is an underlying process of global urbanization taking place. Here, the question of carrying out a part of the transformation process as close as possible to the consumer tends to give a certain degree of freedom. Several innovations are heading in that direction, such as home-brewed beer, homemade mushroom production, the personalized coffee machine, automatic and connected domestic cooking devices with either recipe books or online cooking guidelines. Numerous tools and applications are available to help the consumer in their nourishment (including retail connections, waste management, food procurement, etc.). This dynamic is greatly supported by public policies that increasingly looking for short food supply chains and responsible agriculture (organic or not).

Overall, innovation in food systems is impressively dynamic, and the major challenge is probably going to be to handle the diversity in food systems at every process step. That all studies underline this point is nothing surprising, yet all studies still fail to provide clear pointers on how to innovate and add value at local small-scale level in order to be competitive with globalized and multinationaldominated food systems. Some exceptions are provided by Fellows \& Hampton (1992) and Fellows (2013) for food processing in general, and Valyasevi \& Rolle (2002) for fermentation technologies. New schemes are alluded to, such as those listed in theEU Horizon 2020 program for minor crops, specialized technologies, etc., but there is still no evidence that we are facing a fair future for betterbalanced mass-batch production, large-small volumes, mainstream-coproducts.

If we consider the competitiveness of local small-scale clusters from an engineering point of view, is there evidence that it is achievable? First, local biorefinery concepts are in development to exploit the richness of nature (its biodiversity) and, thus, the use of all components of our food resources. In a way, this seems perfectly logical: if you are dealing with a diversity of (consumer) demands, you should automatically be addressing the biodiversity of the resources to be processed. Second, microand nanotechnology approaches do seem to have potential benefits-but not automatically. Indeed, molecular biology techniques offer the science to tailor starter cultures to a manufacturer's specific requirements (Valyasevi \& Rolle, 2002). The re-introduction of nanotechnology in food processing debates also reflects what is proposed as the third paradigm of chemical engineering (Bruin \& Jongen, 2003), after the first paradigm dealing with unit operations and the second with transport phenomena. This third paradigm deals with understanding organization at levels of increasing complexity with many scales of length and time, and especially their linkages. Interesting here is the fact that the product microstructure manifests itself at a scale that is almost $10^{7}$ smaller than the size of the equipment that has to form the structure-relevant time-scales range from $10^{-8}$, the time necessary for a surfactant to enter a micelle, to $10^{-2}$, i.e. the fusion of two micelles, while molecular dynamics steps have to be roughly $2.10^{-15} \mathrm{~s}$ to accurately follow the fastest vibrational modes of the molecule (Bruin \& Jongen, 2003). In addition, the new science area of electro-thermodynamics may provide new insights at even smaller length and time scales. The underlying questions are: (1) which principles like process efficiency and intensification determine competitiveness at small scale? (2) where are the potential areas for application in the food system?

\section{Methodology}


The methodological approach involves three major pathways to unravel the opportunities for smallscale food process engineering: (1) review of existing processes, (2) process efficiency, intensification and control, (3) best practices for localized application of technologies.

\section{Review of existing food engineering processes}

Numerous publications describe a variety of food engineering processes, often from a historical and innovation perspective. Key examples are the Top 20 listing of the Royal Society (https://royalsociety.org/news/2012/top-20-food-innovations/), the food manufacturing review (Campbell-Platt, 2011), the forward look (De Vries et al., 2009), etc. The most classical approach is the one proposed by Windhab (Fischer \& Windhab, 2011) as the S-PRO2 Scheme to focus food process engineering on structure and property relationships. This complex relation is used to design processes or products at industrial level based on a mechanistic understanding of the relationships. Nevertheless, properties also influence consumer perception, since they are key determinants of physiological and sensorial factors closely related with personalized nutrition-note for example the flurry of recent works highlighting the role of microbiota and eating habits in nutrition. Consequently, developments in the health and care sectors are directly impacted. In addition, food and food engineering are also closely linked to public policies on topics such as food safety and populationlevel nutrition impacts. Figure 1 illustrates the complex interactions at all scales and for various stakeholders-both longstanding and emergent-implying the need for a large diversity of methods and tools to inform food engineering.

After reviewing all key publications in the food science and technology domain, we have adapted the Royal Society's Top 20 listing, as follows:

- Food innovations in past decades: refrigeration, pasteurization, canning, baking, fermentation, frying, the oven, grinding and milling. They are all currently applied at small and large scales.

- Food technologies recognized by all today: irradiation, microwaves, extrusion, aseptic handling, membranes, packaging (active and intelligent). These are more recent innovations, often developed by multinational equipment suppliers - with the support of research centers - for other multinational food manufacturing operations, and consequently they are all applicable now for large-volume, high-throughput processing. Some of the high-tech developments have led to specialty products for high-added-value markets, like a diversity of membranes and targeted packaging developments. These examples may support further initiatives for small-scale process engineering, but not always convincingly from a cost-benefit ratio standpoint.

- Emerging high-potential technologies for tomorrow: ohmic heating, overheated steam, in-pack high-pressure processing, (pulsed) electric fields (for extraction, modification, preservation), biotechnology, extrusion-extraction, cold plasma, membrane emulsification, robotics, and 3D printing. Note that these emerging technologies are often driven by SMEs, thanks to a new generation of highly educated engineers joining or starting these firms. The users are in general still the large manufacturers, due to their capacity to financially invest, but more and more specialty firms for manufacturing niche products are also popping up, again thanks to highlyeducated food scientists. Thus, there is a potential for competitive processing at small scale that is further strengthened by research at the interface of two key domains in physicsthermodynamics and electromagnetism,.

Figure 1. Holistic view of food process engineering 


\section{Process efficiency, intensification and control}

In order to address the question of which of the above technologies may be competitive at small scale, we have to investigate their efficiency, reliability and resilience in a processing environment. Here, we propose to use two approaches: the first dealing with process intensification, the second with process control. Process intensification is considered a first-line pathway in chemical engineering to (a) increase the functionalities of single equipment positioned in parallel, (b) reduce the manufacture space and production facilities, and thus costs, and (c) improve efficiency in terms of energy, water, etc., and thus lower the environmental impact (Stankiewicz \& Moulijn, 2003). The European Roadmap of Process Intensification (2007) defines it as "a set of often radically innovative principles ("paradigm shift") in process and equipment design, which can bring significant (minimum factor 2) benefits in terms of process and chain efficiency, capital and operating expenses, quality, wastes, process safety".

Process control has been introduced in the past decades to improve processing steps via feedback and feedforward controls receiving information from on-line monitoring tools. Process control also enables processing steps to be formalized and steered remotely. The main bottleneck for process control is not the quality and diversity of numerous existing algorithms but the relevance and applicability of sensors used. After a long development pipeline of methods and related engineering approaches (mainly based on computers), it is well recognized that model-based control is the most efficient approach (Trystram, 2011). Recent works focusing on the cost and performances of sensing devices have led to the introduction of new sensor technologies. The future of process control also looks bright. Despite new sensor developments, the use of human-based real-time measurements is still valuable and relevant (Trystram, 2011), mainly at farm or end-user level. Note that without relevant and reliable automatic control systems (and eventually decision support systems), the engineering of small-scale operations and processes remains challenging due to the relatively short residence times for food being processed and the requirement to stick to appropriate quality criteria.

\section{Best practices for localized application of technologies}

The domain of food engineering and its applications is so diverse that we propose to use some best practices for small-scale applications in two core stages of food processing: immediately after harvest and at-home preparation (Figure 2). The applications can span single-food sectors like microbreweries, at-home preparation of single products like beertender and coffee-capsule machines, single resources with multiple output products for different industrial sectors like biorefinery concepts, or multiple resources for multiple-output products like in agroparks. From those best practices, generic conclusions will be drawn taking into account the specific contexts of the cases.

Figure 2. Overview of the food processing domain and potential interventions for down-sizing

\section{Illustrations and Results}

Even if the engineering of small-scale unit operations and processes is a relatively new direction, there are still some illustrations to present. Here, for food engineering, we distinguish different localizations, as described above. First we give an example of re-engineering at farm level, namely for wine extraction. Second, we show an example of re-engineering at end-product and user level, 
namely the potential of 3D printing. Third, we discuss the opportunities of re-engineering concepts at small scale at the farm-industry interface via the case of bio-refining cereals. Here, we add the notion of re-engineering at territory level within new concepts such as AgroParks.

\section{Small-scale processes for the extraction of grapes and plant cell material}

During the traditional winemaking process (maceration of entire grapes), only $40 \%$ of the compounds of interest located in the grape skins (mainly phenolic compounds and aroma precursors) are extracted, whether with intact or crushed grape harvest or by carbonic maceration technology. The INRA, particularly through its Pech-Rouge experimental unit, has carried out numerous experimental projects since the 1970 s to improve such extractions.

\section{a. Thermo-extraction}

The first initial work dealt with several techniques of heating the grape harvest (generally dubbed 'thermo-extraction'). The coupling of time and temperature and the adaptation-to-process of various vine varieties have been intensively studied (Bénard et al, 1980; Barillère et al, 1986). The grapes, warmed between $65^{\circ} \mathrm{C}$ and $75^{\circ} \mathrm{C}$, were pressed after a maceration time ranging from 20 to 40 minutes, allowing alcoholic fermentation in a liquid phase. The extraction of anthocyanins and pigments was equivalent to classical winemaking techniques. The corresponding wines were amylic, a sensory characteristic that corresponded to the market requirements at that time. The limits of this process concerned an observed loss of color, due to a deficit of extracted tannins (Auw et al, 1996), and a loss of aroma during the months following winemaking. These wines were intended for a short shelf-life storage period (few months) and did not correspond to the quality level of AOP (Appellation d'Origine Protégée) wines (Escudier et al, 2008). The stability of the final wine color was improved by fermenting all the thermo-treated grape harvest including all solids, leading to more structured wines, but with a loss of their fruity/amylic properties. Later, in the 2000s, the experiments on grape thermo-treatment were revisited to improve the extraction levels. The duration of the heat maceration phase was increased boldly from 6 to 15 hours (hot pre-fermentation maceration), and its effect was mainly studied on the grape varieties from Languedoc-Roussillon in France (Cotterau et al, 2007). The level of must clarification and the choice of the thermal profile during alcoholic fermentation were shown to be essential parameters for orienting the aromatic profile of such wines to fruity or amylic notes (Cotterau et al, 2007; Eudier et al, 2011).

\section{b. Flash-release treatment}

Flash-release treatment is a powerful extractive technique that consists in submitting a pre-heated $\left(85-95^{\circ} \mathrm{C}\right.$ ) grape harvest to an immediate vacuum (50-60 mbar). The rapid evaporation of the water found in the entire berries, and in particular in the skins, induces a disintegration of cellular tissues, which favors the extraction of skin compounds in the absence of oxygen (Moutounet et al, 2000; Ageron et al, 1995). Experiments performed in liquid phases showed that flash-release treatment extracts at least as many polyphenols as the optimized thermo-treatment technology (Morel-Salmi et al, 2006) while also doubling the extraction of polysaccharides (Mikolajczak et al, 2011). Additions of enzymes were also tested but had practically no effect on polyphenols extraction and only significantly increased polysaccharides extraction (by two orders of magnitude). The fruity notes and color are much more stable in flashed wines than thermo-treated wines because the extraction reveals the same intensity for all the skin compounds. Winemaking in the presence of solids after flash-release treatment concerns quality grapes, in a similar logic as for AOP and IGP wines 
(Moutounet et al, 2000). In this case, the gains in terms of extraction are important and well balanced. An average $50 \%$ gain in phenolics extraction was shown in comparison to the classical winemaking process (maceration of entire grapes after crushing). The experiments demonstrated that the typicality and quality of wines obtained through flash-release treatment followed by maceration during fermentation were estimated as characteristics of the AOP to which the grape harvests belong. The corresponding wines are robust and tannic while keeping their typicality and presenting a certain sweetness if the grape harvest has ripened well. The stability of these wines during aging is improved, thus substantially extending their shelf life. This process was the object of two international patent registrations concerning grape processing (Escudier et al, 1993 and 2013).

Due to its extractive power, flash-release treatment was applied to other vegetables for various applications, which have also been patented. On salad and onion, the flash-release process was applied to extract high-value molecules from plant sorting gaps (such as phenolic compounds) without the use of organic solvents. Coupling flash-release treatment to purification on resin and drying (by atomization or freeze-drying) yielded a phenolics-rich powder. This process was validated and patented (Goupy et al, 2003). On banana, flash-release treatment coupled with the use of enzymes was able to liquefy banana mash (or puree) to obtain a $100 \%$ banana juice, which at the time was entirely new to market shelves. This process was also patented (Minatchy et al, 2002). On tomato and fruits, flash-release treatment yielded, after refining, mashes (or purees) presenting consistencies and viscosities that were clearly superior to classical products.

\section{c. Other tested extraction technologies}

Microwaves have been used to rapidly warm-up grape harvest for either thermo-treatment or flashrelease processes. Despite being easy to handle, particularly to treat small quantities, it is still not a viable option to use them in real-world production due to their huge demands in immediate electric power, at levels of electrical energy way beyond what can be made available in small cellars. Besides, they do not bring any extra extractive performance. Ultrasound has also been tested, but appeared difficult to use and only led to limited extraction rates. Cell-cracking technology (high pressure (4060 bars) followed by a pressure release at atmospheric pressure) has been considered as well, but appeared to be very difficult to operate, and did not give gains in term of extraction (Osse et al, 1987). An alternative extraction process that merits attention in the future is pulsed electric fields (PEF), (Fox et al, 2007).

In conclusion, compounds of interest located in the skins of grapes or other plant cells are very difficult to extract. Various extraction technologies have been tested on grapes to increase the extraction at the end of alcoholic fermentation. Pre-treatment of grapes by thermo-extraction before fermentation gives good results, but is clearly improved when the process is immediately followed by pressure relaxation under strong vacuum (flash-release treatment). Microwave, ultrasound and cellcracking technologies failed to give significant results, and proved hard to operate at industrial scale.

\section{End-product-user technologies and 3D printing as key example}

Classical domestic technologies and equipment used by restaurants are batch operations. Dedicated studies are relatively scarce, and only the thermal and heating performances have been documented at length. Oven, pan-frying and baking equipment have been studied to a point, mostly in studies 
focused on the efficiency of heat transfer (Cernela et al., 2014, Miranda et al., 2010; Dagerskog, 1979). Other equipment has been studied, but innovations in this field are often presented to market without any sound scientific basis described in the literature. Equipment innovation may also be based on a combination of technologies to obtain original performances. A recent example is the Nutripulse e-cooker as new kitchen equipment (http://www.innovationxl.com/uploads/Brochure2013/Nutri-Pulse_e-Cooker_2013.pdf). The kitchen innovation called Nutripulse can cook meat, fish and vegetables in minutes while keeping taste. It is based on the application of electric field pulses that changes the structures of foods: cells are disrupted, and cell walls become permeable. The food becomes eatable, chewable and digestible. The preferred temperature is reached by ohmic heating. The preparation is carried in specially-designed baskets that are placed in the Nutripulse vessel in which the pulses are applied. It seems a simple and potentially practical option for use in the out-of-home and kitchen environment.

We now turn to focus on 3D printing in France for designing new end-products for either at-home, out-of-home or (semi-)industrial-level use.

Additive manufacturing, or ' $3 \mathrm{D}$ printing', is an emerging technology that is expanding into various industrial sectors. It uses material adhesion processes to obtain a final part layer-by-layer from a digital 3D model (ASTM, 2012). One of the most widespread 3D printing processes, called fused deposition modeling (FDM), stems from two classical thermoplastic processing techniques: extrusion and welding. The layer-by-layer deposition of a thermoplastic filament is done by fusing the solid material into a molten state, which can then extrude through a nozzle at high temperature. During cooling, generally at ambient temperature, the filament both solidifies and adheres by welding to the previous layer, in a deposition process that continues until the solid finished part is obtained (Fig.3a). More and more applications are under development for food, opening up broad perspectives for innovative reverse engineering approaches in the design of food products with expected properties or structures (Chaunier et al., 2016).

Figure 3. (a-) Schematic representation of a 3D printer by fused deposition modeling (FDM). (b-) Linkage between FDM-based reverse engineering optimization and additive manufacturing. CAD: Computer-aided model, MIS: Machine instructions, PRT: PaRT, MDL: MoDeL, MSH: MeSHing, PRD: PReDiction

Reverse engineering works to the principle of targeting optimal food design based on predefined output criteria. The advantage of using this approach is to decrease the number of attempted experimental trials. As a process that directly implements a computational model into real objects, FDM can provide the necessary link that makes reverse engineering approaches reliable for smallscale food processing (Fig.3-b). FDM-based reverse engineering can be directed towards personalized diet and desired texture or food properties by manipulating constraints like shape, inner airiness, surface texture, fragmentation and chewing expectations. The development of personalized food as in 3D-printed confectionary requires updates on food design using a design generator that feeds an optimization tool with possible design solutions to be evaluated (Guessasma \& Bassir, 2010).

Structure generators are devised with the idea of finely controlling food microstructure, such as the airy character and its microstructural anisotropy (Guessasma \& Della Valle, 2009). Whether the structure generator is cooperative (Guessasma, 2008) or sequential (Guessasma \& Bassir, 2010), the inferred design needs to reflect the complexity resulting from food transformation technologies with 
a fairly small number of variables. Food engineering based on this approach needs to handle physical constraints that represent the texture score of the virtually-designed food item. More often than not, this score is based on a mechanical evaluation (Mamlouk \& Guessasma, 2013) that reflects the stiffness, yielding behavior, irreversible straining, and strength of the food. This same evaluation is also translatable into sensory attributes (hardness, cohesiveness, crispness, etc.).

However, a successful integrated approach should combine virtual design possibilities with a material science approach for effective control of process-structure-properties relationships. In the context of protein transition, plant proteins could be used as model systems. Additive manufacturing thus emerges as a typical new way of engineering small-scale operations.

\section{Processing and biorefining durum wheat cereals at small scale, and the potential of agripark approaches}

The processing rationale for cereals is presented here for traditional durum wheat-based products, especially those produced in the Mediterranean Basin. The Mediterranean diet has a solid reputation worldwide for its health benefits, welfare and pleasure. It is also recognized by Unesco and features as the first non-material asset on the cultural heritage list. However, the related consumption model is under threat from the globalization of food chains and products, which may have negative impacts on the health status of consumers (obesity, diabetes, CVD, etc.) or on the unique social, economic and environmental performance of local food chains.

Indeed, rural-urban migration, urbanization and social change in the southern Mediterranean areas have resulted in a drastic decrease in the consumption of traditional products (Sissons et al., 2012). Recent years have witnessed a clear shift towards western consumption patterns, in particular towards cheap fast foods. These "new" food products are most often made from cheaper imported agro resources, with the result that overall quality is lower, diversity of traditional food products is reduced, and the entire local food supply chain-including farming-is made to struggle .

The rehabilitation of the Mediterranean diet in these countries needs public support, appropriate policies - that should focus on promoting traditional local products rather than the global market players' food and health strategies-and competitive small-scale re-engineering tools. Looking at cereals, there is a diverse range of durum wheat products revealing the rich Mediterranean culture (Sissons et al., 2012; Trafoon, 2016). Therefore, a new strategy based on small scale processing for various traditional productions and, if relevant,related innovations needs to be developed.

Such an approach has to start with a deeper understanding of the physical, biochemical and technological foundations of quality for these traditional food products and of the diversity of renewable resources required to produce them. Detailed analytical data must be obtained about texture, flavor, health-related compounds, potential safety issues, etc. in order to gain a firm understanding of the diversity of products and their unique character. This understanding would serve to develop a sound system for defining labels and setting standards in order to protect these local products and support policy actions for their development.

For processing, the understanding of physical and molecular changes at nano, micro and meso scales during transformation of heterogeneous agro resources will serve the design and development of appropriate downsized technologies. The core of the approach will be based on a reverse 
engineering strategy considering sensorial, nutritional, economic and cultural attributes of the wide range of traditional food products elaborated at craft or home level. Then, innovative processes can be developed taking into account targeted grain fractionation steps and food structuring methodologies while maintaining or obtaining the required attributes. Instead of homogenization, large volume and high throughput, we should be heading towards heterogeneity and diverse process-structure-function relationships. This means mass and energy transfer balances during unit operations should be adapted accordingly. A first instrumented micro-mill is developed, as part of the INRA's national platform for transformation of plant-based materials in Montpellier, together with detailed models of grain structures and final product functionalities (Rosa-Sibakov et al., 2015).

In order to further increase the competitiveness of small-scale processing of durum wheat products, early new biorefinery concepts have been proposed, tested and described in detail in a recent review article (Abecassis et al., 2014). This basics here are cascading processes to valorize all durum wheat plant parts, including lignocellulose, according to volumes and value (from large volumes and low prices at the bottom to low volumes at high values at the top). This may only be possible if new biorefinery engineering concepts are developed that are efficient at small scale and, in parallel, enable heterogeneous resources to be transofmed for multiple end-products.

In the further future, the competitiveness could be further increased in new cluster concepts, for example agriparks (Smeets et al., 2011) An agribusiness park is defined as a purposive clustering of agriculture-related and non-agriculture-related activities at an industrial estate or in a specific area, offering potentially interesting prospects for closing cyclic processes, reducing transport and making efficient use of scarce space (Wilt et al. 2000: Smeets 2011). This definition underlines the connection between agribusiness complexes and the principle of industrial ecology. Industrial ecology involves linking various industrial engineering processes in order to maximize the exchange of waste and by-products. This not only saves costs, but also minimizes waste production and hence the unfavorable effects of industry on ecosystems. Standout examples include Pomacle in France, Agriport A6 in The Netherlands, Kalundborg Industrial Symbiosis in Denmark, the Hangzhou Dengta Livestock Farm in China, and as an example at urban level, the Agrotechnology Park Singapore.

\section{Discussion and conclusion}

Different principles (physical, chemical, biological) provide opportunities to develop small-scale operations and processes. The generic principles underlying the various technologies are distinguishable by the features as being time- and length-scale-dependent. Process intensification and process control can also be viewed as functions of time and length scales. Some considerations can help differentiate between:

- very-long-duration processing (over 30 minutes); examples are marinades or specific fermentations for added-value products.

- $\quad$ moderate-time processing (1-30 minutes); this concerns the majority of food products widely processed in high-throughput systems today, like heating, milling, filtering, etc.

- very-short-time processing (below 1 minute down to $\mu \mathrm{s}$ ); applications of electrical (magnetic) fields, plasmas, adiabatic/volumetric heating-encompassing, for example, high pressure processing (HPP) - fall in this category.

- nano-micro-scale processing, from $1 \mathrm{~nm}$ up to $100 \mathrm{~mm}$ scales. Nano- and micro-scale technologies are of course different but both are relevant in several cases. 
- meter-scales: often batch-scale processing, like fermentations and retorts.

- Over-10-m scales: high-throughput, large-volume processing, such as in microwave tunnels, and continuous extrusion, generally non-used and non-relevant for small-scale operations.

In general, transfer time and reaction kinetics constraints have to be reconsidered in all kinds of processing schemes at different time and length-scales in order to exploit competitive small-scale technologies. Kinetics profiles substantially change under combined operating conditions like pressure-temperature changes. Heat transfer is exponentially increased due to adiabatic heating via increased pressurization (Matser et al. 2004). Chemical reactions are either accelerated or tremendously inhibited. Knorr (1998) pointed out that the use of pulsed electric fields may have different impacts, such as increasing radical-scavenging potential due to induced oxidative stress, the gating of membranes and thus increased transfer of matter, the inactivation of microorganisms, etc. Mastwijk \& Nierop-Groot (2010) described applicationsof electrical fields, either pulsed like PEF or continuous like plasmas, as if we at entering a new domain of 'electro-thermodynamics' science. Whether discussing the impact of free electrons on bio-matter (food or non-food, living or non-living matter) or the thermodynamical state of bio-matter on external forces, in both cases we are dealing with the dynamics of the density of electrons in matter, and thus with subatomic length scales. These examples well illustrate the fact that the engineering of new unit operations and processes, even at small-scale, necessitates the co-consideration of transfers, transports and reactions, which thus requires modeling and complex system considerations.

Numerous principles are available at all scale, and the technologies are ready, even in scaled down engineering approaches. Below is a series of essential considerations:

- The kind of technologies and their competitiveness

- The link between those technologies and the complexity of matter, the field of electrothermodynamics and the options in fermentation, as molecular biology techniques allow science to tailor starter cultures to the manufacturer's specific requirements; the upshot is that it is possible to obtain an enormous diversity of products.

- The utilization potential of these technologies locally: in combining the technologies, their efficiencies and localized options, we have adapted the science cube, as proposed for the European Network of Excellence project HighTech Europe with two similar axes (scientific principles and unit operations) alongside a third axis on innovation rate to select the potential technologies for small-scale application.

- The importance of cluster thinking and overall valorization across sectors; we have to underline that the market today is fully governed by large-volume processing and in the hands of multinationals; achieving a competitive position for small-scale processing is therefore hard, but not impossible.

- Innovation in technologies and product streams, but also in organizing clusters and striving for joint competitiveness.

One of the advantages of looking at small-scale operations and processes is that extrapolation can be driven not by classical scale-up but by numbers, as more manufacturing sectors get factored in.

\section{Perspectives}


In order to support a transition towards fair food security based on competitive local-global food systems, we recommend the following four actions based on an integrated eco-design approach for process engineering, food science, socioeconomics, and management:

- Better characterize the main options by understanding the complexity of the system and its products, and by identifying new dynamic patterns, based on an integrated vision and multioutput products, taking into account different contexts and levels of development in the various countries to date

- Clarify the choice of technology and its technology readiness level in the bioeconomy and identify ways to improve effectiveness at small-scale using economic (added value, competitiveness, clustering, circular economy), environmental (energy, water, greenhouse gas emissions, biodiversity, loss, mitigation, etc..), and social (employment, food security, cultural values, ethics, urban habitats, etc.) criteria

- Modes of food-system governance. Between "over-empowerment" of consumers and regulation of supplies towards more self-organized and competitive, localism-driven clusters: identify, test and evaluate public and private levers for the best sustainable solutions

- A science program focused on the determinants, characteristics and potential outcomes of the variability of raw materials, the end-products and the related process-intensification, biorefinery and industrial ecology concepts.

These four actions could best be included in an in-depth foresight study with a limited number of scenarios and recommendations, e.g. for the European Commission and regional initiatives. 


\section{Literature}

Abecassis J., de Vries H., Rouau X., 2014. New perspective for bio-refining cereals. Biofuels, Bioproducts and Biorefinery 8: 462-474

Ageron D., Escudier J-L., Abbal P., Moutounet M., 1995. Prétraitements des raisins par flash-détente sous vide poussé. Revue Française d'œnologie, 153, 50-53.

ASTM. F2792-12a, Standard Terminology for Additive Manufacturing Technologies. 2012. ASTM International, West Conshohocken, PA (US).

Auw J-M., Blanco V., O’keefe S.F., Sims C.A., 1996. Effect of processing on the phenolics and color of Cabernet Sauvignon, Chambourcin, and Noble wines and juices. American Journal for Enology and Viticulture, 47, 279-286.

Barillere J-M., Benard P., Vannobel C., Chabas J., 1986. Etude statistique des caractères analytiques de vins obtenus par différentes techniques de vinification après chauffage de la vendange. Sciences des Aliments, 6, 201-211.

Benard P., Bourzeix M., Flanzy C. 1980. La vinification avec chauffage de la vendange. Résultats de 10 années d'expérimentation. http://prodinra.inra.fr/record/108752

Bruin S., Jogen Th.R.G. (2003) Food process engineering: the last 25 years and the challenges ahead. Comprehensive Reviews in Food Science and Food Safety, 2, 42-81.

Campbell-Platt Geoffrey (2011) Food Science and Technology, John Wiley \& Sons ISBN: 978-0-632-06421-2.

Cernela J., Heyd B., Broyart B., 2014Evaluation of heating performances and associated variability of domestic cooking appliances (oven-baking and pan-frying). Applied Thermal Engineering, 62, 758-765.

Charpentier J., 2010. Among the trends for a modern chemical engineering, the third paradigm: The time and length multiscale approach as an efficient tool for process intensification and product design and engineering. Chemical Engineering Research and Design 88, 248-254. 
Chaunier L., Leroy E., Della Valle G., Dalgalarrondo M., Bakan B., Marion D., Madec B., Lourdin D., 2016. 3D printing of maize protein by fused deposition modeling. Proceedings of the $32^{\text {nd }}$ Annual Conference of the Polymer Processing Society. Melville, N.Y., AIP Publishing L.L.C.

Cottereau P., Desseigne J-M., 2007. Chauffage de la vendange et arômes fruités. CR Entretiens viti-vinicoles Rhône-Méditerranée (31 mai 2007), Narbonne, France, 20-22.

Dagerskog M., 1979. Pan frying of meat patties. A study of heat and mass transfer. LebensmittelWissenschaft und Technologie, 12, 217-224.

De Vries H., van Boekel T., Linnemann A., 2009. Current systems and future scenarios in food processing. In ESF/COST Forward Look on European Food Systems in a Changing World; IREG, Strasbourg; ISBN: 2912049-96-2; 65-93

De Wilt J.G., van Oosten H. J., Sterrenberg L., 2000. Agroproduction parks:perspectives and dilemmas. Den Haag, Innovatienetwerk Groene Ruimte en Agrocluster.

Escudier J-L., Mikolajczak M., Bes M., 2008. Chauffage de la vendange : les technologies disponibles et les méthodes de vinifications associées. Revue Française d'CEnologie, 229, 9-18.

Escudier J-L., Mikolajczak M., Favarel J-L., Williams P., Doco T., 2013. Procédé de préparation d’un produit alimentaire liquide enrichi en oligosaccharides et en polysaccharides. Brevet FR N 1158819.

Escudier J-L., Moutounet M., Cogat P.O., 1993. Produit alimentaire, obtention et application à la fabrication de jus de fruit et de vin. Brevet FR Nº 9313287.

Eudier L., Samson A., Caille S., Aguera E., Bes M., Dangleville G., De Vlieger L., Salmon J.M., 2011. Le décanteur centrifuge Alfa Laval. Apport d'un nouvel outil pour le prétraitement de la vendange thermotraitée avant fermentation. Revue des CEnologues, 1386, 18-20.

FAO, 2010, Definition of sustainable Diets, international scientific symposium, Biodiversity ans sustainable diets against hunger, Rome, FAO, 2 pages 
Fellows P \& Hampton A. (1992) Small-scale food processing; a guide for appropriate equipment. Published by Intermediate Technology Publications, 103-105 Southampton Row, London WC1B 4HH, UK. ISBN 1 853391085 http://www.fao.org/Wairdocs/X5434E/x5434e00.htm\#Contents

Fellows P., 2013. Complete manual for small-scale processing. ISBN-13: 978-1853397660

Fischer P, Windhab E.J., 2011. Rheology of food materials. Current Opinion in Colloid \& Interface Science, 16, 36-40.

Fox M.B., Esveld D.C., Boom R.M., 2007. Conceptual design of a mass parallelized PEF microreactor. Trends in Food Science \& Technology, 18, 484-491.

Goupy P., Amiot Carlin M-J., Escudier J-L., Mikolajczak M., Martin M., 2003. Procédé d'extraction, de fractionnement et de purification de composés phénoliques issus de plantes potagères feuillues de la famille des liliacées ou d'écarts de triage de végétaux frais utilisant une résine à haut rendement d'adsorption et d'élution. Brevet FR Nº 0102096.

Guessasma S., 2008. Young's modulus of 2D cellular structures under periodic boundary conditions and subject to structural effects. Computational Materials Science, 44, 552-565.

Guessasma, S., \& Bassir, H.D. (2010). Optimization of the mechanical properties of virtual porous solids using a hybrid approach. Acta Materialia, 58, 716-725.

Guessasma S., Della Valle G., 2009. Generation of anisotropic cellular solid model and related elasticity parameters: Finite Element Simulation. Journal of Cellular Plastics, 45, 119-36.

Knorr D., 1998. Technology aspects related to microorganisms in functional foods. Trends in Food Science \& Technology, 9, 295-306.

Miranda J.M., Martínez B., Pérez B., Antón X., Vázquez B.I., Fente C.A., Franco C.M., Rodriguez J.L., Cepeda A., 2010. The effects of industrial pre-frying and domestic cooking methods on the nutritional compositions and fatty acid profiles of two different frozen breaded foods. Food Science and Technology, 43, $1271-1276$. 
Mastwijk H.C., Nierop-Groot M.N, 2010. Use of cold plasma in food processing. In: Encyclopedia of biotechnology in agriculture and food, Heldman D.R., Hoover D.G., Wheeler M.B. - [s.I.] : Taylor \& Francis, ISBN 9780849350276, 174-177.

Matser A.M., Krebbers B., van den Berg R.W., Bartels P.V., 2004. Advantages of high pressure sterilisation on quality of food products. Trends in Food Science \& Technology, 15, 79-85.

Meynard J.M., Jeuffroy M-H., Le Bail M., Lefèvre A., Magrini M-B., Michon C., 2016. Designing coupled innovations for the sustainability transition of agrifood systems. Agricultural Systems, in press.

Mezzenga R., Schurtenberger P., Burbidge A., Michel M., 2005. Understanding foods as soft materials. Nature Materials, 4, 729-740.

Mikolajczak M., Veyret M., Williams P., Doco T., Escudier J-L., 2011. Jus de raisin: comment extraire le maximum du potentiel de la baie de raisin. Revue Française d'CEnologie, 249, 1-10.

Minatchy N., Mikolajczak M., Escudier J-L., 2002. Procédé d’obtention de produits dérivés de bananes, notamment de liquéfaction de la banane en vue d'obtenir un pur jus. Brevet FR N 0206545.

Morel-Salmi C., Souquet J-M., Bes M., Cheynier V., 2006. Effect of flash-release treatment on phenolic extraction and wine composition. Journal of Agricultural and Food Chemistry, 54, 4270-4276.

Moutounet M., Escudier J-L., 2000. Prétraitement des raisins sous vide, incidence sur la qualité des vins. Bulletin de I'OIV, 73, 827-828.

Nutripulse (2016) http://www.innovation-xl.com/uploads/Brochure2013/Nutri-Pulse_e-Cooker_2013.pdf

Osse C., 1987. Le « cell cracking » : nouvelle technique pour la désintégration des matières brutes végétales. Application au raisin, aux fruits et au bois. Laboratoire de microbiologie Wagenigen - INRA UE Pech Rouge. 53 p.

Perrot N., De Vries H., Lutton E., van Mil H.G.J., Donner M., Tonda A., Martin S., Alvarez I., Bourgine

P., van der Linden E., Axelos M., 2016. Some remarks on computational approaches towards sustainable complex agri-food systems. Trends in Food Science and Technology, 48, 88-101. 
Perrot N., Trelea I.C., Baudrit C., Trystram G., Bourgine P., 2011. Modelling and analysis of complex food systems: State of the art and new trends. Trends in Food Science \& Technology, 22, 304-314.

Porter M.E., 2000. Location, competition, and economic development: Local clusters in a global economy. Economic Development Quarterly, 14, 15-34.

Rastoin J.L., Ghersi M., DeSchoutter O., 2010. Le système alimentaire mondial, Versailles, Editions Quae.

Rosa-Sibakov N., Poutanen K., Micard V., 2015. How does wheat grain, bran and aleurone structure impact their nutritional and technological properties? Trends in Food Science \& Technology, 41, 118-134.

Sissons M.J., Abecassis J., Marchylo B., Carcea M., 2012. Durum Wheat: Chemistry and Technology; Second Edition; ISBN: 978-1-891127-65-6; 300 pages

Smeets P.J.A.M., 2011. Expedition agroparks. Research by design into sustainable development and agriculture in the network society (320 pages); ISBN: 978-90-8686-163-7.

Stankiewicz A., Moulijn J.A., 2003. Re-engineering the chemical processing plant: Process intensification. CRC Press

Trafoon (2016); https://www.trafoon.eu/

Trystram G., 2012. Modelling of food and food processes. Journal of Food Engineering, 110, 269-277.

Trystram G., 2009. Automatic control and optimisation of food processes. From food engineering understanding to food process control, EFFoST, 2009, Budapest.

UN (2016) http://www.un.org/sustainabledevelopment/sustainable-development-goals/

Valyasevi R., Rolle R.S., 2002. An overview of small-scale food fermentation technologies in developing countries with special reference to Thailand: scope for their improvement. International Journal of Food Microbiology, 75, 231-239.

Van der Sman R.G.M., Goot A.J., 2009. The science of food structuring. Soft Matter, 5, 501-510. 
Fig.1

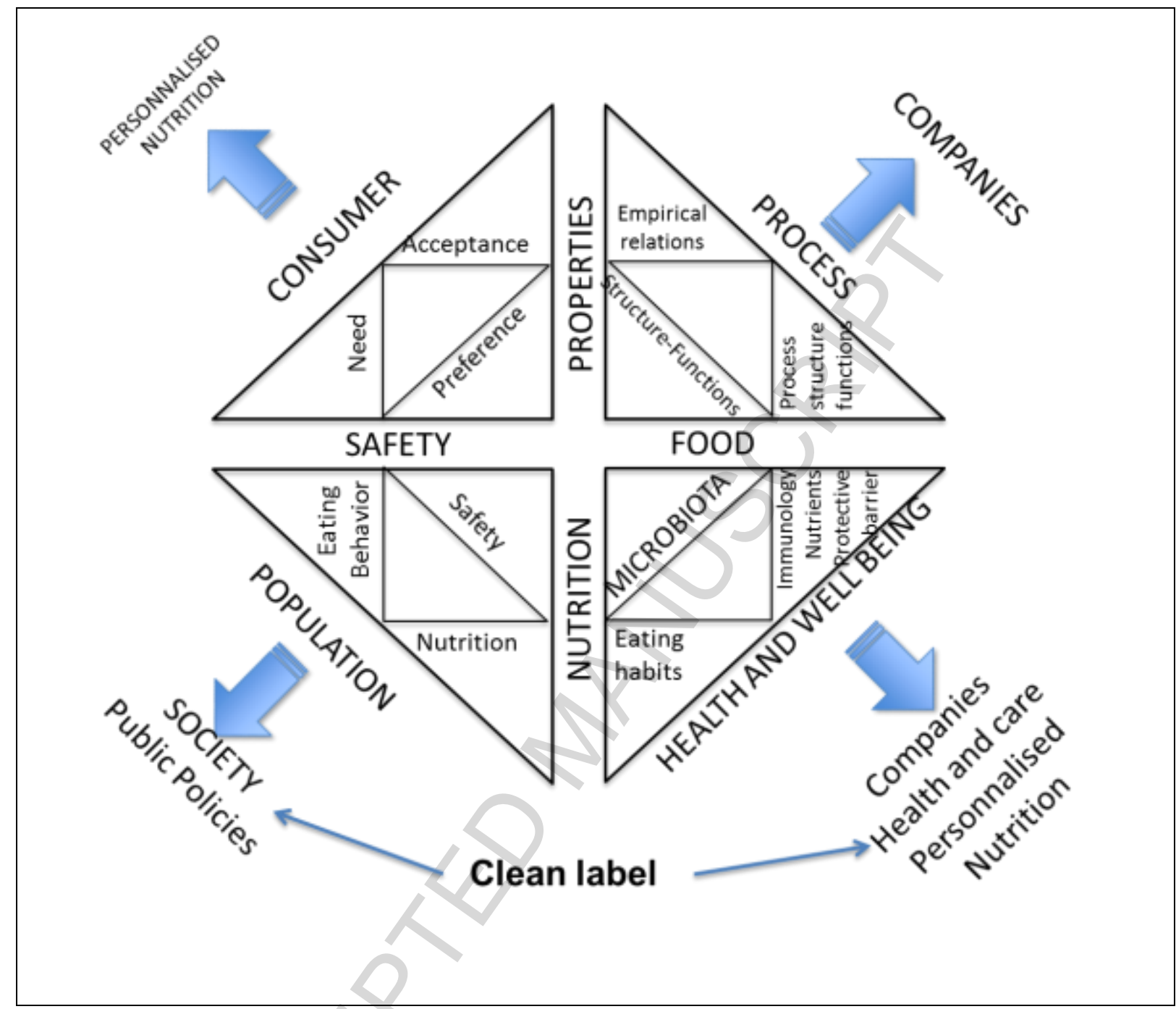


Fig. 2.

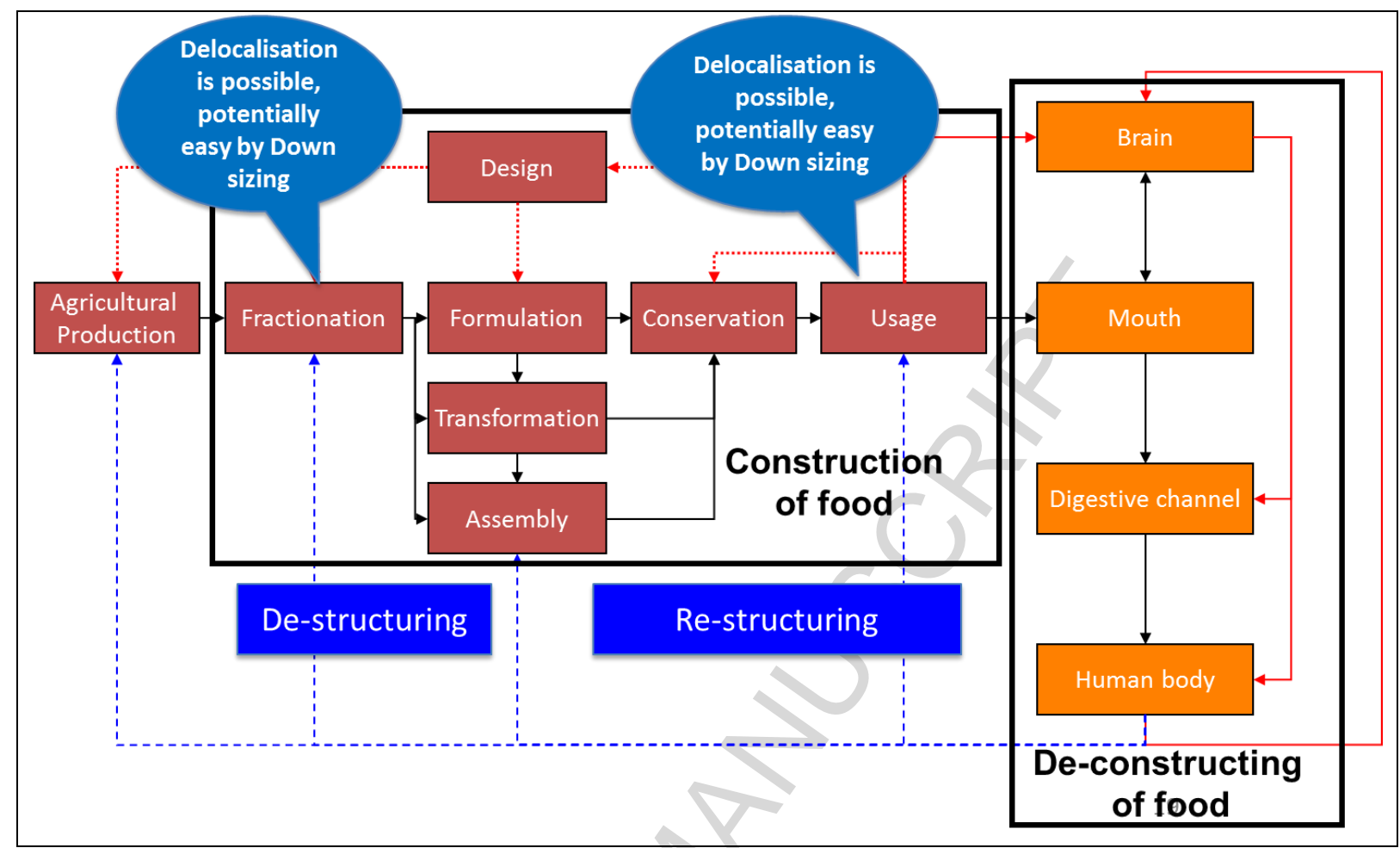


Fig. 3.

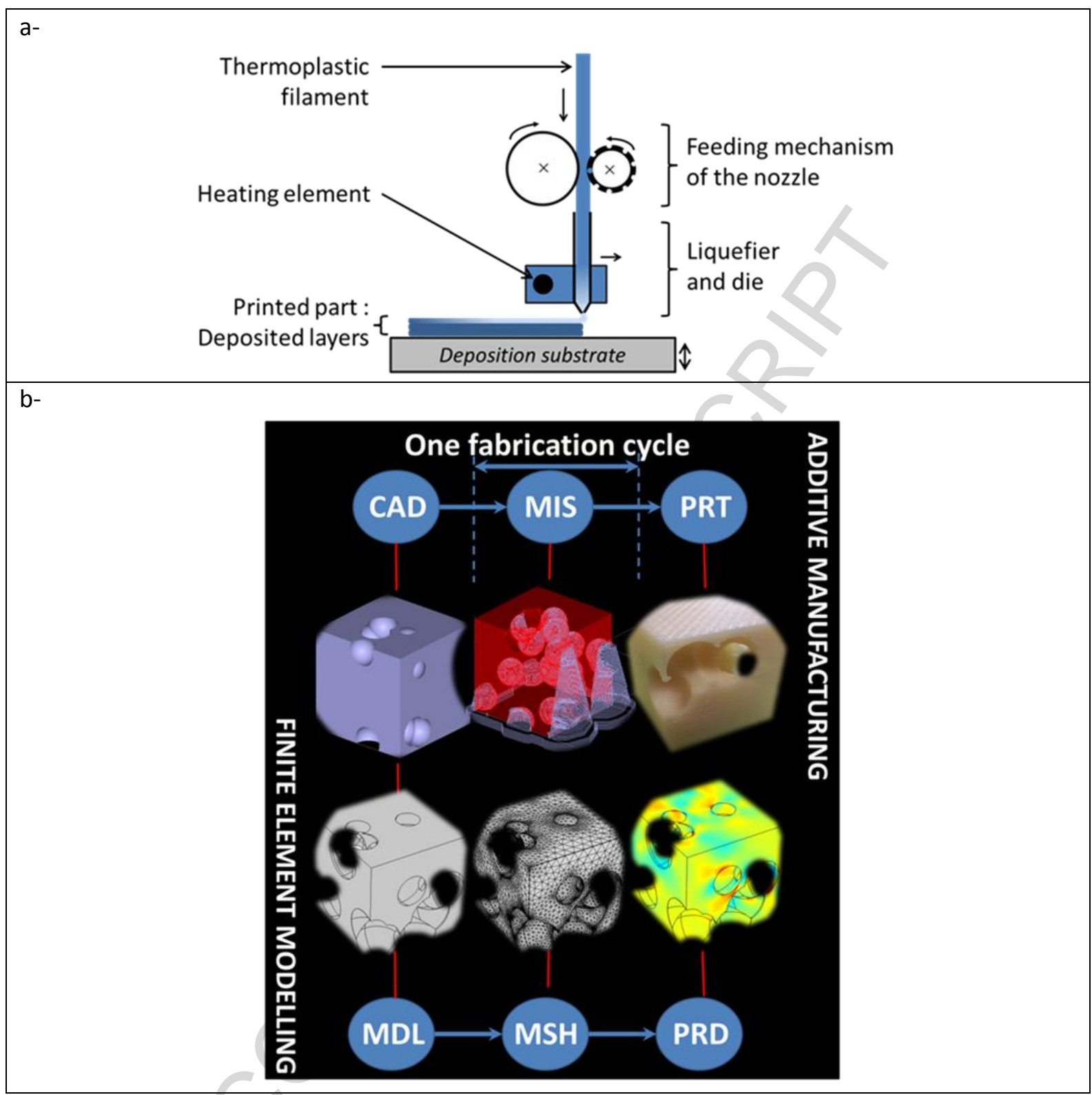


Figure captions to "Small-scale food process engineering - challenges and perspectives"

Fig. 1.

Holistic view of food process engineering

Fig. 2.

Overview of the food processing domain and potential interventions for down-sizing

Fig. 3.

(a-) Schematic representation of a 3D printer by fused deposition modeling (FDM). (b-) Linkage between FDM-based reverse engineering optimization and additive manufacturing. CAD: Computer-aided model, MIS: Machine instructions, PRT: PaRT, MDL: MoDeL, MSH: MeSHing, PRD: PReDiction 
Highlights of 'Small-scale food process engineering - challenges and perspectives':

- Process efficiency and reliability may make small-scale processing competitive.

- Small-scale processing is fit and feasible after harvest and close to consumption.

- Custom-printed foods with targeted structure are designed by reverse engineering.

- Small-scale biorefinery concepts can valorize biodiverse resources locally.

- Innovative local food and bioproduct systems should consider novel technologies. 